\title{
The Public Perception of Privatization in Poland from 1991-2014*
}

\author{
Wiktor Patena, Renata Stawiarska**
}

\begin{abstract}
Summary: The purpose of the paper was to conduct a quantitative analysis of relations between privatization goals, their effects and results of public opinion concerning privatization. Out of several metrics of the privatization results confronted with people's attitudes to privatization only two were statistically significant. Contrary to the first hypothesis, people's attitudes toward privatization is not a function of periods of prosperity or economic slowdown (measured by the WIG20, and GDP growth). The only variable it is correlated to is the unemployment rate (correlation -0.6577). Obviously, opinions people form about privatization are mostly based on their personal experiences, especially those related to unemployment. The attitude towards privatization varies and depends on the proximity of the phenomenon to respondents.

The changing V-shaped public attitude to privatization can lead to a conclusion that Poles seem to have passed through a learning process while transformation progressed. The process began with a great deal of enthusiasm for free market transformations, followed by disillusionment resulting from layoffs and unemployment. But then the momentum gained by the transformation process was already large enough to carry the Polish economy forward, together with people's perception of privatization process, further on the road to economic prosperity. On the other hand, the V-shape may soon easily be easily reversed. The results of the 2015 presidential election are symptomatic here. They coincide with most recent general sentiment for statism and economic nationalism.
\end{abstract}

Keywords: the privatization process, privatisation in Poland, quantitative analysis, economic transformation

\section{Introduction}

Over the past 25 years, privatization has been one of the most significant developments in the economy and public policy in Poland. The Polish experience with privatization is similar to developments in neighbouring central European countries. However, the privatization process (although controversial) was slower and less dramatic than for example in Germany, where the Treuhandanstalt (a trust corporation with the task of transforming public agencies into private enterprises) President, Detlef Rohwetter, had been assassinated (retribution for the misfortune of the east Germans) (Legge 2003: 2).

Bałtowski and Kozarzewski in their seminal book (Bałtowski 2014: 391) conclude a series of surveys by CBOS (opinion polls centre) and observations of their own by making

\footnotetext{
* The work was supported by Narodowe Centrum Nauki (National Science Centre, Poland) under grant number DEC-2012/05/B/HS4/03546.

** Wiktor Patena, PhD, Higher Colleges of Technology, Abu Dhabi, United Arab Emirates, e-mail: wiktor.patena@ gmail.com; Renata Stawiarska, MA, Miasteczko Multimedialne Sp. z o. o., Nowy Sącz, Poland.
} 
a statement that Polish society does not have a feeling that they have benefited from privatization. They also point out to the dualistic nature of the social perception of privatization. People are convinced that privatization may be beneficial economy-wise, but tends to be detrimental in the individual dimension. Another phenomenon is that opinions on privatization and its effects are related to the general attitude towards the market economy. Those citizens who are of the view that the free market is the best economic system, more often pay attention to the benefits of privatization, while critics of the free market system usually speak negatively about the process of privatization and its consequences, both individual and collective.

The privatization process, that involved the sale of state-owned enterprises and other forms of privatization, has generated elaborate literature, which often neglects the process by which citizens form attitudes toward privatization policies. In 2015 at the point when the privatization process in Poland comes to an end, it is high time to sum up its history, achievements and confront them with the public's perception of the process. This article contributes to addressing this gap in the literature through an analysis of the public perception of privatization in Poland. The purpose of the paper is to complement the CBOS surveys (they were terminated in 2009) and IPSOS survey (commissioned by the Ministry of Treasury in 2012), TNS survey (commissioned by the Ministry of Treasury in 2013) by making another in 2014, and then perform a profound, quantitative analysis of the surveys' results by confronting them with various privatization metrics. We believe that public opinion, and not only the effects of the privatization process, is an important issue for policymakers considering privatization initiatives.

There are two hypotheses to be posed:

1. Perception of privatization is a litmus test for the success of the transformations in Poland. People's attitude toward privatization does not depend on particular measures of its success such as privatization revenues, number of privatized companies or improvements in their performance, but is a function of periods of prosperity or economic slowdown.

2. Perception of privatization is also a function of proximity. People often approve the idea of systemic transformation in terms of changing the ownership structure but are oppose to employment reductions and company liquidations especially if they happen close to where they live.

Most papers on privatization focus on analysing the process and its results. The issue of the social perception of privatization appears occasionally (Bałtowski 2014; Raport 2014; Błaszczyk 2007; Kozarzewski 2007; Staniszewski 2007; Frentzel 1993). Bałtowski (2014: 390-394) comments on it when discussing the political goals of privatization. He states

\footnotetext{
${ }^{1}$ CBOS - Centre for Public Opinion Research is an opinion polling institute in Poland. Established in 1982, CBOS conducts a monthly survey on a representative sample of 1,000 adult persons entitled "Current Problems and Events". TNS Polska - a part of the TNS Global Market research company, established in 2012 after the merger of Pentor Research International SA and OBOP Sp. z o. o. IPSOS Loyalty - part of the international research group IPSOS.
} 
that the expectation behind privatization, though never written expressis verbis, was that the ownership changes would create powerful lobbies that would foster the free market transformations and would be interested in continuing the process. However, throughout the transformation period, and irrespective of the government's efforts, privatization turned to be the reform which was granted very little public support. Privatization was often blamed for all of the misfortune and flaws of the Polish economy, and has never become a factor that could guarantee support of Polish society for a free market policy. Kozarzewski (2007: 64) gives reasons for this, pointing out to many mistakes made in privatization policy: lack of long term strategy, unrealistic expectations, inefficient privatization methods, politics dependency, imperfect governance over SEO and the process of their privatization.

In contrast, Błaszczyk (2007: 7) emphasizes that from the very beginning there were influential groups that lived off the state owned companies and objected to privatization (trade unions and SOE management) and some political elite - opponents to privatizationthat were using any arguments to prove that state owned is always better and privatization is tantamount to stealing or giving away national property. They hindered the privatization process and in effect the share of the public sector in the GDP in Poland is nowhere near the levels noticed in most developed Western economies.

Soon after the fall of communism, the issue was analysed by Frentzel (1993). She states that the level of public support for a newly emerging system, as well as attitudes toward specific areas of government intervention, constitute a very important aspect of social and economic life in post-communist societies.

The issue is also raised in annual reports prepared by the Ministry of Treasury. One of the most recent reports (Raport 2014: 27) quotes a survey carried out by CBOS (2012) according to which $37 \%$ of respondents have positive associations related to privatization. Opinions vary depending on the region. Negative opinions dominate in the south-eastern regions of Poland. The perception is also determined by the economic status of respondents and their education. Still, $42 \%$ of the respondents (only $38 \%$ in 2004, but $46 \%$ in 2012) claim that privatization was indispensible for building a free market economy in Poland.

The topic, as a separate issue, was analysed only by Staniszewski (2007). He concludes that the social perception of privatization in 1991-2006 changed dynamically along with the progressive process of the property transformation of the Polish economy. It was determined by two categories of factors: economic and social. At a certain point in time privatization (seen via personal experience) became a synonym of unemployment and public rejection to support privatization was reflected in the surveys. The analysis was divided into 4 periods (hope 1990-1991, clash of expectations with reality 1992, stabilization 1993-1998, destabilization since 1999) leads to his conclusion that privatization is "accepted only in an economic dimension (ideological and symbolic layer)".

The analysis was based on opinion polls results carried out by CBOS in 1990-2006. In the first chapter the hypotheses are verified by confronting various measures of privatization results (corresponding to major goals of privatization) with the results of the CBOS 
surveys. The obvious correlations, or their lack of, are the premises to draw conclusions. In the second chapter, a separate survey that complements CBOS opinion poll results is presented and analysed. It is an attempt to create a series of opinion poll results that cover the period 1991-2014.

\section{Privatization Goals vs. Metrics and their Social Perception}

The program of industry reform, including privatisation, was a political decision of the first Polish government after the fall of communism in 1989. However, there have been various more specific goals behind privatisation. Kozarzewski (Bałtowski 2014: 107) divides the goals of ownership changes into three categories. Here are the premises behind the goals and metrics of the results used in the chapter to measure to what extent the goals were achieved.

- main goals: systemic, microeconomic,

- additional goals: fiscal, social, political,

- side goals: stopping wild privatization, development of financial institutions.

\section{Table 1}

Goals, definitions, metrics

\begin{tabular}{|c|c|c|c|}
\hline No. & Goals & Definition & Metric \\
\hline $1 . \mathrm{a}$ & Systemic & $\begin{array}{l}\text { changing the ownership structure, reducing the role of the Sta- } \\
\text { te in those industries where exercising corporate government } \\
\text { by institutions of public administration is not necessary }\end{array}$ & $\begin{array}{l}\text { number of privati- } \\
\text { zed companies }\end{array}$ \\
\hline 1.b & Microeconomic & improving the competitiveness and performance of companies, & return on sales \\
\hline 2.a & Fiscal & generating revenues from the privatization process & $\begin{array}{l}\text { privatization reve- } \\
\text { nues }\end{array}$ \\
\hline 2.b & Social & $\begin{array}{l}\text { boosting economic growth (lowering unemployment), finan- } \\
\text { cing social security reforms }\end{array}$ & $\begin{array}{l}\text { GDP growth, } \\
\text { unemployment rate, } \\
\text { opinion poll results }\end{array}$ \\
\hline 2.c & Political & $\begin{array}{l}\text { creating privatization beneficiaries that would support the } \\
\text { transformation process }\end{array}$ & election results \\
\hline 3.a & $\begin{array}{l}\text { Stop to wild priva- } \\
\text { tization }\end{array}$ & $\begin{array}{l}\text { stopping the process of taking over companies by their "no- } \\
\text { menklatura" management }\end{array}$ & N/A \\
\hline 3.b & $\begin{array}{l}\text { Development of the } \\
\text { financial market }\end{array}$ & growth of the capital market and the Warsaw stock exchange & WIG20 index \\
\hline
\end{tabular}

Source: Bałtowski (2014): 372 (column 1 only).

Some premises behind privatization were obvious. For example, it was the conviction that state-owned enterprises (SOE) are sustainably ineffective and it is rather impossible to create an effective system of government supervision over SOE. Hence, it was taken for granted that privatisation is to positively affect the economic performance of privatized companies and improve the whole economy. Trying to assess the privatization process, one often tries to measure whether the assumed result was achieved (e.g. the privatized companies perform better). If so, another question arises. Does the public notice, accept 
and legitimize the process? We will try to find out how the metrics shown in Table 1 correspond with the results of the surveys carried by the CBOS. There are two benchmarks we use to confront with other data. Both come from the CBOS surveys, which are presented in Table 2. However, for the use of comparisons, the data was scaled down to one number and presented as a difference between yes/beneficial and no/adverse answers.

\section{Table 2}

Selected data from the CBOS surveys ${ }^{2}$ - attitude to privatization (1) and perception of the economic situation (2)

$\begin{array}{llllllllll}1991 & 1993 & 1995 & 1997 & 1999 & 2001 & 2003 & 2005 & 2007 & 2009\end{array}$

\begin{tabular}{|c|c|c|c|c|c|c|c|c|c|c|}
\hline \multicolumn{11}{|c|}{ 1. Is privatization beneficial for the Polish economy? } \\
\hline beneficial & 42 & 36 & 33 & 40 & 32 & 20 & 19 & 25 & 27 & 30 \\
\hline neither beneficial nor adverse & 30 & 29 & 28 & 31 & 28 & 37 & 28 & 27 & 34 & 41 \\
\hline adverse & 9 & 21 & 20 & 16 & 27 & 33 & 43 & 40 & 29 & 20 \\
\hline hard to say & 19 & 14 & 19 & 13 & 13 & 10 & 10 & 8 & 10 & 9 \\
\hline \multicolumn{11}{|c|}{ 2. Was the passing year good for the Polish economy? } \\
\hline yes & 12 & 14 & 28 & 31 & 20 & 8 & 12 & 26 & 35 & 29 \\
\hline neither yes or no & 28 & 41 & 45 & 39 & 44 & 32 & 34 & 47 & 36 & 39 \\
\hline no & 53 & 36 & 18 & 21 & 31 & 55 & 48 & 19 & 24 & 29 \\
\hline hard to say & 6 & 9 & 9 & 9 & 5 & 5 & 6 & 8 & 5 & 3 \\
\hline
\end{tabular}

Source: Prywatyzacja - oceny skojarzenia... (2012); BS/174/2012.

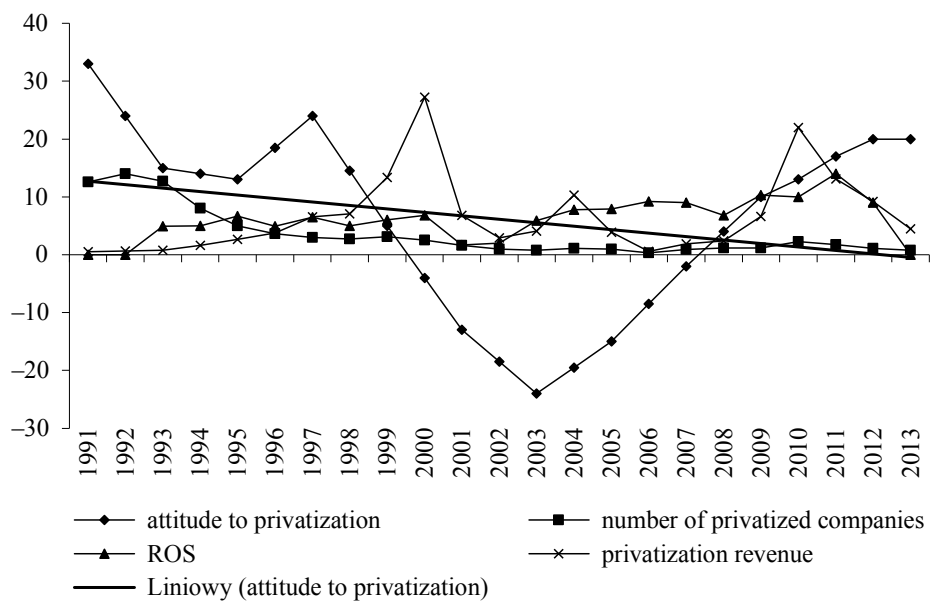

Figure 1. Privatization revenue, number of privatized companies and ROS vs. social attitude to privatization

Source: GUS, CBOS reports, MSP data.

${ }^{2}$ Surveys were performed via face-to face surveys supported with CAPI (computer assisted personal interviewing) on a representative sample of 900-1,000 adults. 
The first analysis covers goals 1a, $1 \mathrm{~b}$ and $2 \mathrm{a}$ introduced in Figure 1. In terms of the goals, neither ROS nor the privatization revenues seem correlated with the social perception of the privatisation. Some positive correlations last only for short periods such as 2000-2002 and then 2008-2010. This is confirmed by the correlations shown in Table 3.

\section{Table 3}

Correlations: attitude to privatization vs. privatization revenue,

ROS and number of privatized companies ${ }^{3}$

\begin{tabular}{lc}
\hline Correlations $(-1: 1)$ & Attitude to privatization \\
\hline Number of privatized companies & 0.2975 \\
ROS & -0.1018 \\
Privatization Revenues & 0.2070 \\
\hline
\end{tabular}

Source: own elaboration.

Figure 2 covers goals $2 \mathrm{c}$ and $3 \mathrm{~b}$ (politics and financial markets). The views on privatization have changed significantly over the last 25 years. Since privatisation decisions were politically justified, it is not surprising then that the revenues from the privatisation process strongly correspond with politics. The revenues were highly dependent decisions made by political parties that were in power at different points of time. One aspect of the analysis of revenues from privatisation is worth noticing. Some Ministers fully used the economic opportunities (booming markets) for increasing revenues from privatisations, whereas others squandered the chance the market offered. For example, in the years 2003-2007 the stocks were extremely bullish, but there was no political will to generate revenues from privatisation. In the years 2007-2009 the markets were bearish (financial crises) which made it very difficult to accomplish the privatisation plan. Then the markets recovered and the privatisation revenues also sky-rocketed. In 2007 after political change in the governing party the privatization process became one of its priorities. It was emphasized by the Prime Minister Donald Tusk in his expose: 'There is no better protection against politicians interfering in the management of companies than a real increase in the competitiveness of Polish companies and the Polish economy. This is achievable by wise, fast and dynamic privatization'. The acceleration of the privatization process was clearly visible. The number of privatized companies rose significantly - notably in 2010. With the increase in the number of privatized companies, revenues from privatization also rose. The year 2010 brought the highest revenue in the analysed period of time - 22 billion PLN.

Surprisingly, the relation between politics and revenues is not reflected in the opinion poll results (Table 4). For example, in 2003-2007 the public support for privatization policy seems to have increased, but it is worth mentioning that this is the period when privatization

\footnotetext{
${ }^{3}$ To avoid a non-stationarity problem, the analyzed data were modified (non-stationarity is typical for financial time series data). The data was transformed to a stationary process by differencing $S_{t}$ and $S_{T}$, where: $d s_{t}=\ln \left(S_{T} / S_{t}\right)$, and the process became difference stationary.
} 
was almost stopped. However, in the period to follow (2008-2010) privatization revenues start growing rapidly, and the process is still supported by the public. After a long period of disapproval, in 2003 the public opinions about privatization reversed. The possible reason for this could be the dynamic growth of the WIG20 and other stock indexes which started in 2003 and lasted until 2007, and which obviously made the public forget about their previous opinions concerning privatization. Privatization is tantamount to less politics in the economy - the statement was one of the premises behind privatization. In general however, it seems that the public did not expect this to happen. On the contrary, a lot of people still approve of the idea of state control of business.

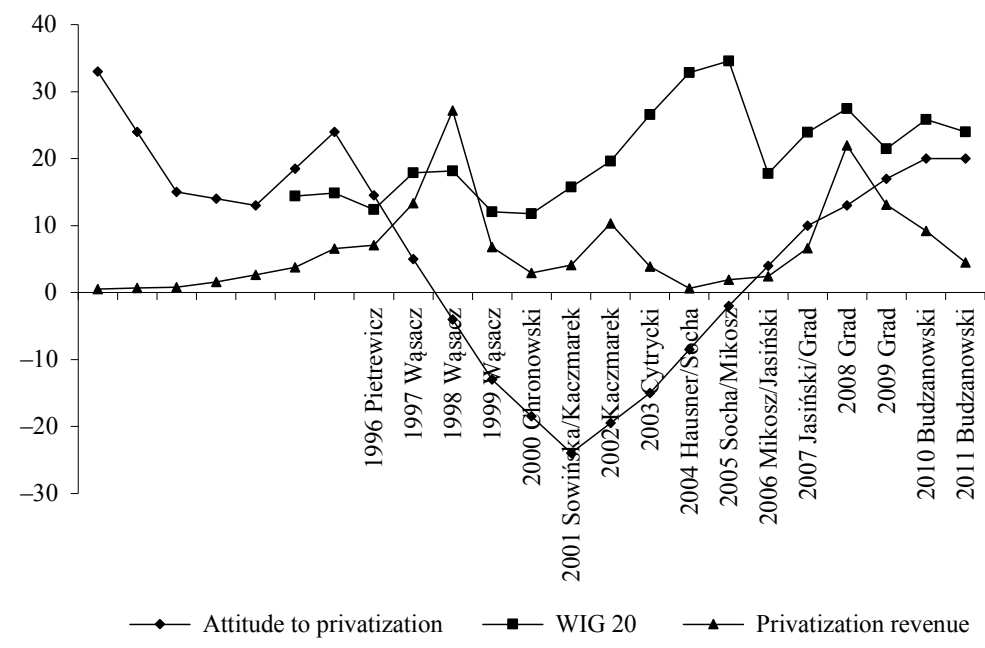

Figure 2. Privatization revenue and the WIG20 vs. the social attitude to privatization Source: MSP data and GPW data.

\section{Table 4}

Correlations: attitude to privatization vs. The WIG20 and privatization revenue

\begin{tabular}{ll}
\hline Correlations $(-1: 1)$ & Attitude to privatization \\
\hline WIG20 & 0.1418 \\
Privatization revenues & 0.2070 \\
\hline
\end{tabular}

Source: own elaboration.

Figure 3 covers goals $2 \mathrm{~b}$ (social goals proxied by economic growth and unemployment rate metrics). Having ignored the data from 1991-1996 (radical differences between the analysed time series must be attributed to the general confusion of the public in the first years after the collapse of communism), one can notice a clear negative relation between people's 
attitude to privatization and unemployment rate (correlation -0.6577). GDP growth, however, is not correlated with people attitude to privatization at all $(-0.0169)$, nor is it a perception of the economic situation (-0.1077). Anyway, the results (Figure 3, Table 5) lead to the conclusions partially consistent with the first hypothesis. People's attitude toward privatization does not depend on particular measures of its success such as privatization revenues, number of privatized companies or improvements in their performance, but is a function of periods of prosperity or economic slowdown, measured mostly by those down to earth metrics (unemployment rate) and not the abstract ones such as GDP growth. Obviously, unemployment was the most immediate and dramatic effect of layoffs being often the consequence of the privatization process and it is not surprising that the public perception of privatization is so strongly correlated with this variable.

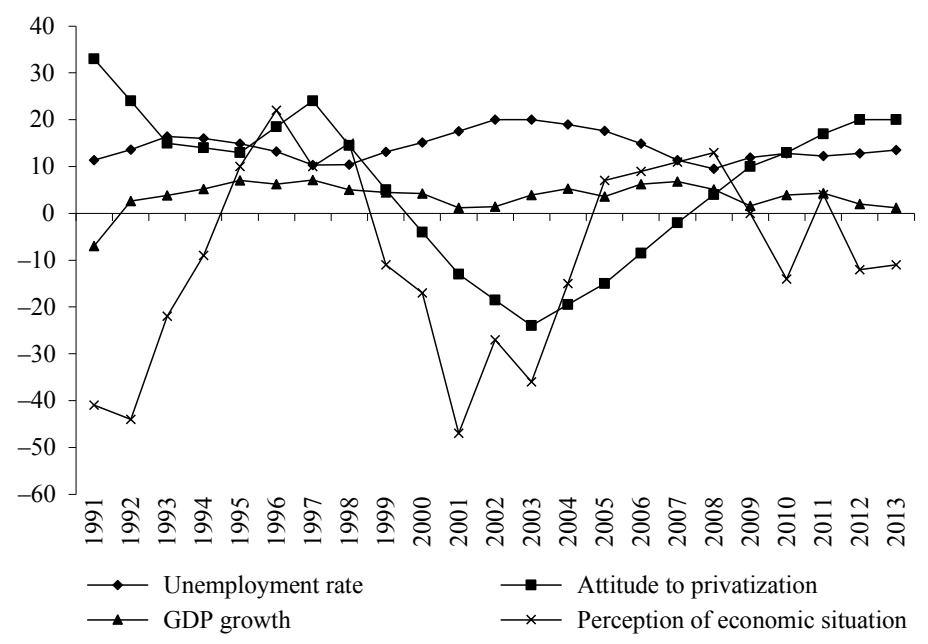

Figure 3. GDP growth, unemployment rate and perception of economic situation vs. the social attitude to privatization

Source: Prywatyzacja... (2009); Oceny roku 2012 i prognozy na rok 2013 (2012); BS/174/2012.

\section{Table 5}

Correlations: attitude to privatization vs. GDP growth, unemployment rate and perception of the economic situation

\begin{tabular}{ll}
\hline Correlations $(-1: 1)$ & Attitude to privatization \\
\hline Unemployment rate & -0.6577 \\
GDP growth & -0.0169 \\
Perception of the economic situation & -0.1077 \\
\hline
\end{tabular}

Source: own elaboration. 
It is also worth emphasizing that public views on privatization could have been formed by the media that often pliubcised spectacular, negative examples of privatization. This effect was not taken into account in the research, as it is beyond the potential of a quantitative analysis.

CBOS in their surveys carried out in the years 1990-2009 asked 3 basic questions (compare: Table 2):

1. Is privatization beneficial for the Polish economy?

2. Is privatization beneficial for you personally?

3. Is privatization beneficial for the employees of privatized companies?

Thus, people's attitude towards privatization can be estimated, not in just one (analyses above), but in three dimensions. The data (answers to 3 questions) was scaled down (compare Table 2) to one number and presented as a difference between yes/beneficial and no/ adverse answers. As it can be seen in Figure 4 and Table 6 the answers are highly correlated (0.6726 and 0.9549). What is more, consistently with the second hypothesis, both Figure 4 and the correlations in Table 6 prove that the attitude towards privatization varies and depends on the proximity of the phenomenon to respondents. They often pay lip service to the idea of privatization and its benefits for the whole country, but become much more critical when it comes to their own well-being, especially when they happen to be the employees of privatized companies.

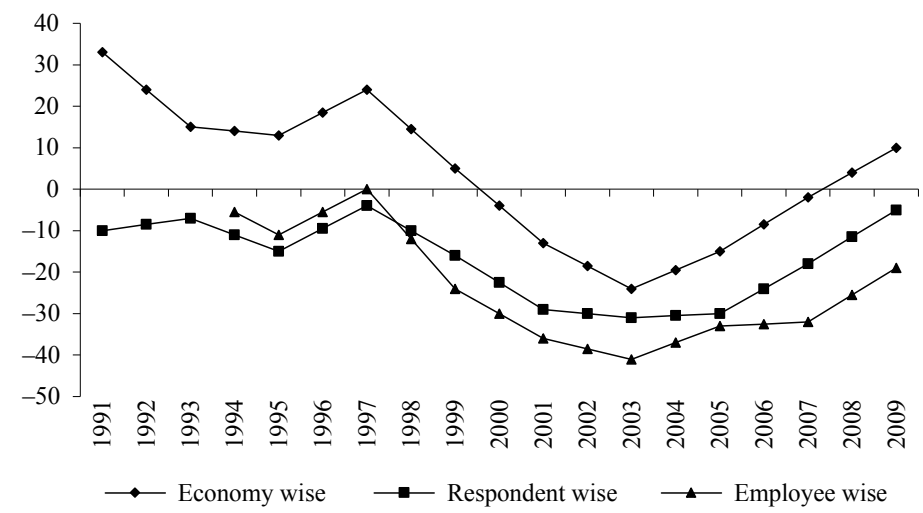

Figure 4. Proximity vs. the social perception of privatization in 3 dimensions

Source: Prywatyzacja ... (2009).

Table 6

Correlations: attitude to privatization: economy wise vs. respondent and employee wise

\begin{tabular}{ll}
\hline Correlations $(-1: 1)$ & economy wise \\
\hline respondent wise & 0.6726 \\
employee wise & 0.9549 \\
\hline
\end{tabular}

Source: own elaboration. 


\section{2014 Survey on the Social Perception of Privatization}

The purpose of this part of the research was to explore the opinion of Polish society on the privatization process, their attitude to private vs. state-owned enterprises and complement CBOS opinion polls carried out before 2014. The gathered data leads to the conclusion that the public has clear views concerning the privatization process and its influence on daily life and a market economy. The legal status of a company they work for seems to determine the society's perception of privatization to a large extent. Information gathered from interviewee's shows society's positive attitude to privatization - as the majority of indications are focused on the positive sides of privatization. According to respondents' answers, it can be inferred that society believes that private companies are more likely to adapt to market conditions. Also, the positive influence of private companies on the market was indicated by interviewees by private firms' characteristics in which they point out (innovative, development, high quality products and service, etc.) and all other indications which showed the superiority of private firms over state owned or state controlled companies.

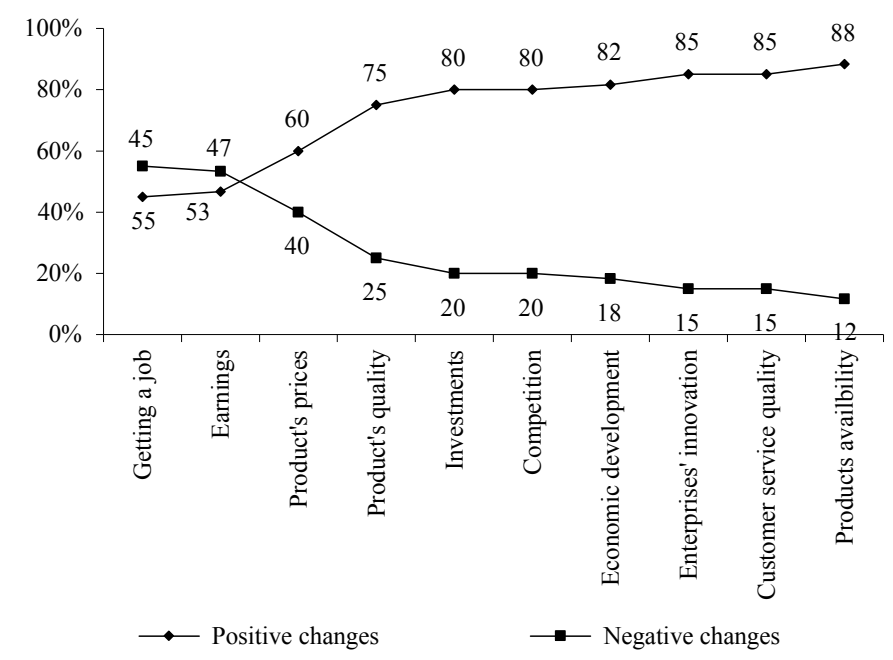

Figure 5. Privatization influence on respondents' daily life

Source: own elaboration.

The survey was carried at the WSB-NLU (Department of Finance) in 2014. The feedback to the survey was $25 \%$, which constitutes 70 responses out of 280 views of the questionnaire. Incomplete questionnaires were excluded from the analyses. Respondents' sample was 60 people $-52 \%$ of women and $48 \%$ of men. More than half of the respondents $(63 \%)$ were people aged 18 to 25 years old, $31 \%$ were people aged 26 to 40 years old, the remaining $6 \%$ of respondents were aged over 40 . 
There are two common approaches to the privatization process. Some people recognize the positive results of privatization; others focus only on its bad sides. To learn respondents' general opinion of this process a question about its affects in their daily life was asked. The majority of respondents recognize the positive changes in the majority of categories ( 8 out of 10). The biggest positive result of increasing the number of private companies is the availability of products ( $88 \%$ of indications). The next two are customers' service quality and level of innovation in companies ( $85 \%$ of indications). Accordingly to respondents' answers the economic development accelerates along with privatization ( $82 \%$ of indications), investments ( $80 \%$ of indications) and the competition in the market intensifies ( $80 \%$ of indications). With reference to products, $75 \%$ of interviewees voted that product quality improves, together with a decline in the price levels ( $60 \%$ of indications). Only in two categories respondents indicated negative changes in life situation arising from public to private transformations: getting a job (55\% of indications) and earnings (53\% of indications).

Referring to the question in which respondents had to decide how the market upturn or downturn will affect state and private companies an interesting dependence was discovered. Figure 6 presents how the interviewees perceived the states' and private enterprises ability to take advantage of market opportunities and to overcome difficulties. In times of market upturn, accordingly to respondents' opinions, state companies will generate $10 \%$ more revenues, while private companies will achieve a $15 \%$ increase in sales. On the other hand, during market downturn private companies will lose $15 \%$ of their revenues and sales in state owned companies will drop by $18 \%$. Respondents seem to believe that a private company is able to handle in a more effective way market growth and avoid bigger losses in sales while in times of recession.

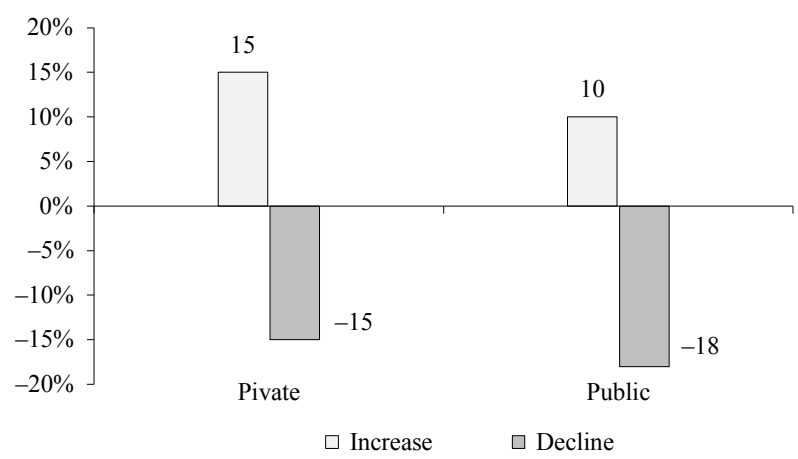

Figure 6. Influence of market condition on state and private companies

Source: own elaboration.

According to the Ipsos Loyalty (2012) analysis conducted for the Ministry of Treasury almost half of respondents (46\%) agreed with the statement that privatization was necessary to build a market economy in Poland. Every third respondent thought the opposite (35\%), 
and nearly $20 \%$ could not take any position with regard to this issue. However, state and private companies were still perceived differently, mostly in terms of remuneration and safety of employment. Table 7 presents the results of another set of questions related to employment and the legal status of ownership. By analysing the answers to the questions (presented as short case studies), in which the legal status of ownership could determine respondents' indications, it is easy to recognize interviewees' approach to the privatization process.

One can notice that the interviewees perceived an obvious trade-off between salaries and employment security in state and private companies. Employment in a state company is more secure, but salaries are lower. In four out of five provided situations, which concern salary, as well as, R\&D budget, private companies were seen as more competitive. In respondents' opinions private companies offer higher salaries. The only advantage of state companies is security of employment.

\section{Table 7}

Attitude to the privatization process and private vs. state companies - comparisons of respondents answers

\begin{tabular}{ll}
\hline $\begin{array}{l}\text { Private } \\
\text { (mean) }\end{array}$ & $\begin{array}{l}\text { State } \\
\text { (mean) }\end{array}$ \\
\hline
\end{tabular}

a If the certainty of employment in a state company is high - at the level of 8 points (out of 10), and the average salary is 3,200 PLN (gross), how high should be the salary in a private company in which job security was rated at 5 points?

b When considering the possibility of working in the same position in two different companies, which amount of salary in the private company would convince you to choose it as a place of work, if the state company offers a monthly salary of 2,200 PLN (gross)?

c A state company allocated 3\% of last year's profit for R\&D (in a budget for the coming year). What percentage in your opinion would a private company allocate?

d If the certainty of employment in a private company is at the level of 5 points (out of 10), and the average salary is 3,200 PLN gross, how would you rate job security (on a scale of 0 to 10 ) in the state company where the average salary is 2,000 PLN gross?

e When considering working in the same position in two different companies which amount of salary in a state company would convince you to choose it as a place of work, if a private company offers permanent employment with a monthly salary of 2,300 PLN.

NOTE: bold numbers are data provided in questions.

Source: own elaboration.

In addition to historical data (Głuszyński 2005) and the gathered respondents' opinions it was possible to present similarities, differences and changes in society opinion on state and private companies. The areas which were analysed are as follows: better products and service, better management, better competitiveness, higher investment and faster development, influence on the economy, employees' development and job security. As it can be noticed, opinions in three out of seven categories have changed over the years. Nowadays, 
Polish society sees private enterprises as producers of better products and services with better management habits. Nevertheless, it is worth pointing out that the certainty of employment is now higher in state companies.

\section{Table 8}

Historical and recent data comparison

\begin{tabular}{lll}
\cline { 2 - 3 } & Historical data & Recent data \\
\hline Better products, better service & State & Private \\
Better management & State & Private \\
Better competitiveness & Private & Private \\
Higher investments and faster development & Private & Private \\
Influence on economy development & Private & Private \\
Employee development & Private & Private \\
Guarantee of employment & Private & State \\
\hline
\end{tabular}

Source: own elaboration.

\section{Table 9}

Comparisons of opinions on state and private companies

\begin{tabular}{llll}
\cline { 2 - 3 } & $\begin{array}{l}\text { State companies } \\
\text { (range 0-10) }\end{array}$ & $\begin{array}{l}\text { Private companies } \\
\text { (range 0-10) }\end{array}$ & $\begin{array}{l}\text { Statistically significant } \\
\text { difference }\end{array}$ \\
\hline Development & 3.84 points & $\mathbf{7 . 3 1}$ points & YES \\
Competitive prices & 5.45 points & $\mathbf{6 . 9 6}$ points & YES \\
Innovative & 4.49 points & $\mathbf{7 . 4 3}$ points & YES \\
High product quality & 5.37 points & $\mathbf{6 . 7 7}$ points & YES \\
Low operation costs & 4.83 points & $\mathbf{6 . 1 0}$ points & YES \\
Permanent employment & $\mathbf{9 . 1 3}$ points & 4.35 points & YES \\
High employee performance & 5.02 points & $\mathbf{7}$ points & YES \\
Work without stress & $\mathbf{8 . 4 5}$ points & 3.56 points & YES \\
High earnings & $\mathbf{6 . 1 8}$ points & 5.76 points & NO \\
\hline
\end{tabular}

Source: own elaboration.

The legal status determines Polish society's perception of a company. Table 9 presents nine categories evaluated by interviewees - differences in 8 out of 9 pairs are statistically significant, and accordingly to the average scores of all categories - six of them are in favour of private enterprises. Most people see advantages of the privatization process and a private companies operations on the free market.

Accordingly to the gathered data Polish society recognizes the many positive sides of private companies. Avoiding the straightforward question, whether respondents support or not support the privatization process, interviewees were also asked to point out which of the provided actions is the most likely to happen first after the ownership transformation. As it can be seen the respondents are convinced that a private owner will introduce a new 


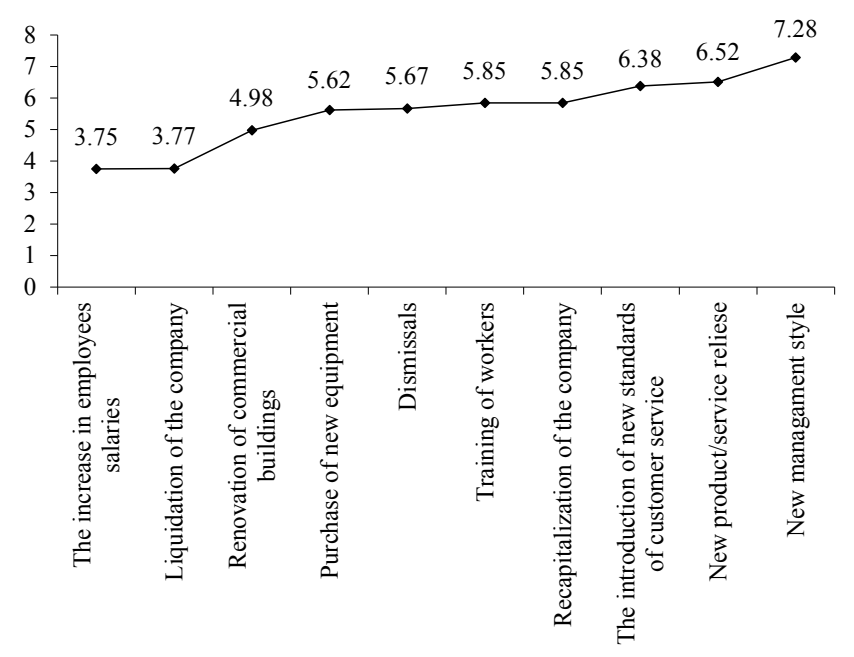

Figure 7. New owner's first decisions

Source: own elaboration.

management style. What is more, the respondents in this survey have indicated that private companies are characterized by low operation costs - surely achieved by good management. The following actions in interviewees' opinion will be positively associated with the launch of new standards of customer's service, new product release, and recapitalization of the company. Respondents decided that the dismissals and liquidation of a company will not be one of the very first moves considered after taking over a company by a private investor. Information gathered from interviewees show a positive attitude to privatization. Respondents evaluated positively potential private investor actions. In light of the results, it seems that the old clichés about privatization are no longer valid.

\section{Conclusions}

Privatization has been a major issue in Poland for over the past two decades, but research on public opinion about it has been scarce. Policy makers and economists were focused on assessing the economic results of privatization. We claim that public opinion, not only affects the privatization process, but is an important issue for policymakers considering privatization initiatives. The public perception is often a reflection of the social effects of privatization and then (via political unrest) may determine privatization policies.

The analysis was based on opinion poll results carried out by the CBOS in 1990-2006. The purpose of the paper was to conduct a quantitative analysis of relations between privatization goals and their effects and results of public opinion concerning privatization. 
Out of several metrics of privatization results (GDP growth, WIG20 level, the number of privatized companies, unemployment rate, privatization revenues, and the ROS, perception of economic situation) confronted with people's attitude to privatization only two were statistically significant.

Contrary to the first hypothesis, people's attitude toward privatization is not a function of periods of prosperity or economic slowdown (measured by the WIG20, and GDP growth). The only variable it is correlated to is the unemployment rate (correlation -0.6577 ). Obviously, the opinions people form about privatization are mostly based on their personal experience. Especially, every time people experience the bad sides of the market, like poverty or unemployment, their attitudes towards privatization become more critical. This finding is consistent with the other tested hypothesis. The attitude towards privatization varies and depends on the proximity of the phenomenon to respondents. They may support the general idea of privatization and its benefits for the whole country, but become much more critical when it comes to their own well-being, especially when they happen to be the employees of privatized companies.

The changing V-shaped public attitude to privatization may lead to a conclusion that people seem to have passed through a learning process while transformation progressed. The process began with a great deal of enthusiasm for free market transformations, followed by disillusion resulted from layoffs and unemployment. But then the momentum was gained by the transformation process as it was already large enough to carry the Polish economy, together with people's perception of the privatization process, further on the road to economic prosperity (Hayo 1993, p. 100). On the other hand, it is very likely that the V-shape may reverse and follow a downwards trend line (compare the trend line in Table 1). The results of the 2015 presidential and parliamentary elections are symptomatic here. They coincide with the most recent general sentiment for statism, re-pollinizing the banking sector, creation of strong Polish capital based groups in the energy, defense, insurance and chemical sectors, which basically are longing for economic nationalism in Poland.

\section{References}

Antczak M. (2007), Kondycja finansowa przedsiębiorstw sektora publicznego w Polsce z perspektywy całej gospodarki i badań empirycznych, in: Przedsiębiorstwa sektora prywatnego i publicznego w Polsce (1999-2005), L. Balcerowicz (ed.), Warszawa: Centrum Analiz Społeczno-Ekonomicznych, pp. 35-46.

Bałtowski M., Kozarzewski P. (2014), Zmiana własnościowa polskiej gospodarki 1989-2013, Warsaw: PWE.

Błaszczyk B. 2007. Mapa sektora publicznego w Polsce jako wynik polityki prywatyzacyjnej, in: Przedsiębiorstwa sektora prywatnego i publicznego w Polsce (1999-2005), „Zeszyty BRE Bank CASE”, nr 89/2007, Warszawa, pp. 7-20.

Breznau N. (2010), Economic Equality and Social Welfare: Policy Preferences in Five Nations, "International Journal of Public Opinion Research" vol. 22, no. 4.

Debardeleben J. (1999), Attitudes Towards Privatisation in Russia, "Europe-Asia Studies" vol. 51, no. 3.

Frentzel-Zagorska J., Zagorski K. (1993), Polish Public Opinion on Privatisation and State Interventionism, "Europe-Asia Studies" vol. 45 , no. 4.

Głuszyńki J. (2005), Opinie Polaków o prywatyzacji, TNS Global Pentor, Warszawa. 
Hayo B. (1997), Eastern European Public Opinion on Economic Issues: Privatization and Transformation, "The American Journal of Economics and Sociology" vol. 56, no. 1, pp. 85-102.

Jawłowski A. (2001), Privatization as a social process. Analysis of employee opinions. Instytut Studiów Politycznych Polskiej Akademii Nauk, Warszawa.

Komunikat z badań BS/174/2012 - Oceny roku 2012 i prognozy na rok 2013. 2012. CBOS, Warszawa.

Kozarzewski P. (2007), Prywatyzacja w Polsce $w$ pespektywie porównawczej. Wyniki ilościowe i jakościowe, in: Zmiany w polskich przedsiębiorstwach, Błaszczyk B. (red), „Raporty CASE”, Nr 70/2007, Warszawa.

Kozarzewski P. 2004. Nadzór korporacyjny $i$ wtórna prywatyzacja $w$ Polsce: ramy prawne $i$ zmiany $w$ strukturze własnościowej, „CASE Studia i Analizy 263”.

Legge J., Rainey H. (2003), Privatization and Public Opinion in Germany, "Public Organization Review" vol. 3, pp. 127-149.

Patena W. (2014), Analysis of the Privatisation Process in Poland in the Years 2008-2011 - Outcomes and Prospects. „Quarterly eFinanse” vol. 10, no. 2, pp. 57-70.

Prywatyzacja - oceny, skojarzenia, oczekiwania i obawy (2009), CBOS, Warszawa.

Prywatyzacja i co dalej. Analiza efektywności funkcjonowania spółek po prywatyzacji w latach 2008-2011 (2012), MSP, Warszawa, pp. 1-8.

Raport o ekonomicznych, finansowych i społecznych skutkach prywatyzacji w roku 2012 (2013), MSP, Warszawa, pp. 1-33.

Raport o ekonomicznych, finansowych i społecznych skutkach prywatyzacji w roku 2013 (2014), MSP, Warszawa, pp. 1-33.

Raport z badania opinii na temat prywatyzacji (2013), IPSOS Loyalty, Warszawa (Survey commissioned by the Ministry of Treasury).

Staniszewski R. (2007). Społeczna percepcja prywatyzacji w okresie transformacji systemowej, „Studia Politologiczne" nr 11, pp. 43-56.

Wojciechowski W. (2010), Prywatyzacja. Wciąż niewykorzystane szanse, Warszawa: Fundacja Forum Obywatelskiego Rozwoju.

\section{PUBLICZNE POSTRZEGANIE PRYWATYZACJI W POLSCE OD 1991-2014}

Streszczenie: Praca ma na celu przeprowadzenie analizy ilościowej postrzegania celów i efektów procesów prywatyzacyjnych przez opinię społeczną w Polsce. Z siedmiu branych pod uwagę miar wyników prywatyzacji skonfrontowanych z opiniami obywateli tylko dwa wyniki okazały się statystycznie istotne.

Wbrew pierwszej hipotezie postrzeganie prywatyzacji nie jest funkcją okresów wzrostu lub spowolnienia gospodarczego (mierzonego przez WIG20 i PKB). Jedyną zmienną skorelowaną z postrzeganiem prywatyzacji jest stopa bezrobocia (korelacja -0.6577). Opinie jakie obywatele tworzą na temat prywatyzacji są często oparte na osobistych doświadczeniach, w szczególności tych związanych z utratą pracy.

Postrzeganie prywatyzacji w Polsce, które badane w czasie przyjmuje kształt litery V, prowadzi do konkluzji, że Polacy przeszli długi proces edukacji w czasie transformacji gospodarczej w latach 1989-2014. Proces zaczął się od wielkiego entuzjazmu dotyczącego gospodarki wolnorynkowej, po którym nastąpiło głębokie rozczarowanie efektami zmian, w tym prywatyzacją. Niemniej tempo wtedy rozpoczętych zmian było na tyle duże, że doprowadziło do długofalowo do gospodarczej prosperity. Z drugiej strony niebawem możemy obserwować odwrotny proces (wyniki wyborów w 2015 są symptomatyczne) będący skutkiem sentymentów narodowościowych, propaństwowych i rosnących sympatii dla etatyzmu.

Słowa kluczowe: proces prywatyzacji, prywatyzacja w Polsce, analiza ilościowa, transformacja gospodarcza

\section{Citation}

Patena W., Stawiarska R. (2016). The Public Perception of Privatization in Poland from 1991-2014. Finanse, Rynki Finansowe, Ubezpieczenia, 1 (79), 723-738; www.wneiz.pl/frfu. 